\title{
THE INFLUENCE OF CELEBRITY ENDORSER ON PURCHASE INTENTION WITH PERCEIVED QUALITY AS MEDIATING VARIABLE
}

\author{
Tharissa Kesturi ${ }^{\star 1}$, Rd. Nurafni Rubiyanti ${ }^{2}$ \\ Universitas Telkom, Indonesia*12 \\ tharissakstr@gmail.com¹ , rubiyanti@gmail.com²
}

\begin{abstract}
The cosmetics industry is projected to continue to experience growth by the Indonesian Cosmetics Companies Association by 15\% to Rp. 11.22 trillion from Rp. 9.76 trillion in 2012. One of the cosmetic brands in Indonesia is Wardah Cosmetic. The purpose of this study was to determine the effect of celebrity endorsers and Wardah Cosmetic's perceived quality on the buying interest. The method used in this research is the quantitative method, with the type of descriptive-causal analysis. Sampling with a non-probability sampling method with purposive sampling type with a sample size of 100 female consumers in the city of Bandung. The data analysis technique used is descriptive analysis technique and Partial Least Square - Structural Equation Model analysis. Based on SEM-PLS analysis, the celebrity endorser variable has a strong effect on purchase intention with a T-Statistics value of 7.486. Based on the moderation effect analysis, perceived quality perfectly mediates with a T-Statistics value of 1.124 . The conclusion of this study, the variable perceived quality effectively influences as a perfect mediator towards celebrity endorsers and buying interest, which means that Wardah Cosmetic's use of celebrity endorsers is appropriate to affect the perceived quality of Wardah Cosmetic products and stimulate consumer buying interest.
\end{abstract}

Keywords: Celebrity Endorser, Perceived Quality, Purchase Intention

\section{INTRODUCTION}

Economic growth in the era of globalization which is currently increasing rapidly makes companies participate increasingly in competing in offering their goods and services to be recognized by consumers. This economic growth is also supported by advances in various industrial fields, one of which is the cosmetics industry. At this time, many cosmetic companies are competing to not only sell the quality of their products to consumers but also to build an attractive brand image to attract consumers to believe in these products to create a relationship between products and consumers.

According to a survey by Euromonitor International, developing countries contribute $51 \%$ to the global beauty industry, including Indonesia, which has a dynamic market in Southeast Asia. It is estimated that Indonesia will become the main growth market for the beauty industry in 2019 (Swa.co.id, 2018). Based on
Government Regulation Number 14 of 2015 concerning the Master Plan for National Industrial Development (RIPIN) for 2015-2035, the cosmetics industry is one of the mainstay industries, namely priority industries that play a major role as the prime mover of the economy. In addition to emphasizing mastery of research and technology to support cosmetic product innovation, it is hoped that the independence of cosmetic raw materials, especially those based on Indonesian nature, is also expected. (Swa.co.id, 2018).

Indonesia, with its 250 million inhabitants, is a potential land for the cosmetics market. This industry is experiencing development with a sales increase in 2012 by $14 \%$ to $\mathrm{Rp} 9.76$ trillion from the previous $\mathrm{Rp} 8.5$ trillion. This increase comes from the growth in the level of demand, especially from middle-class consumers. The cosmetics industry is projected to continue to experience growth by the Association of Indonesian Cosmetics Companies 
(PERKOSMI) by $15 \%$ to IDR 11.22 trillion from the previous IDR 9.76 trillion in 2012.

In the last 10 years, the beauty and personal care industry in Indonesia has grown by an average of $12 \%$ with a market value of IDR 33 trillion in 2016. The unique behavior of consumers in Indonesia is strongly influenced by various factors such as culture, weather, food consumption, and the generation population. young people also make the beauty industry stretch. Reported from http://majalahkartini.co.id/ that the Central Statistics Agency (BPS) 2015 data shows the number of millennials aged 18-30 years in Indonesia reaches $24 \%$ of the total population.

Wardah is present as a local cosmetic, which is one of the original Indonesian cosmetic products specifically targeting Muslim women consumers and all women who want to use cosmetics that are safe and do not contain harmful ingredients and become a pioneer of cosmetics with Halal certification. Halal certification is an authority issued by LPPOM MUI. The success of the Halal message contained in Wardah products is proven by the award for the Halal Award 2011 received by PTI for the category of Halal Cosmetics Brands.

Wardah was also noted to have won the 2016 Indonesia Customer Satisfaction Award for lipstick, loose skin powder, and compact skin powder products, which indirectly expanded the product image while stimulating consumer buying interest from Wardah Cosmetics. Purchase interest is several possibilities where consumers will buy a product or service (Chinomona, 2013). The interest in buying Wardah products is also very influential for women who have made cosmetics a primary need so that it has an impact on the level of sales of these cosmetics. Wardah Cosmetic, which initially fostered buying interest based on sub-religions, turned out to be not only enjoyed by Muslim women and wearing the hijab but also non-Muslim Indonesian women, and $40 \%$ of
Wardah's consumers are non-Muslims. (Enciety.co, 2018). This news is reinforced by the results of the author's interview directly with Dwindry Formanda as the Head of Business Development Office of PT. Paragon Technology and Innovation Bandung branch.

So it can be said that with the great buying interest in Wardah Cosmetic products, consumers have the perception that the quality of Wardah Cosmetic products is good. Customer perceptions will involve what is important to customers because each customer has different interests in a product or service

Advertising is done to bring out the desire of consumers to buy and use the advertised product, but it is also hoped that there will be a method. Kertamukti (2015) states that the definition of advertising is part of the promotion mix and the promotion mix is part of the marketing mix. Advertising is defined as a form of message about a product or service delivered through the media, addressed to part or all of society. Good advertising can lead to a good quality perception of the advertised product.

One of the methods companies use to advertise their products is to use an endorser figure. Celebrity endorsers according to Friedman (1979) in the journal Darmansyah et al (2014) are individuals who are known to the public (actors, sports figures, entertainers, etc.) for their achievements in other fields than the supported product classes. The use of ambassadors or endorsers is carried out by companies to influence or invite consumers. This aims to make consumers interested in using the product, especially because the selection of a brand ambassador or brand endorser is usually based on the image through a well-known celebrity (Putra, 2014). The research results of Damanik (2014) explain that the effect of celebrity endorser (credibility, visibility, attraction, and power) together have a significant effect on buying interest with a total effect of $89.87 \%$. 
While in Mansour \& Diab (2016) it has been shown that celebrity endorsement affects consumer feelings in general and it can affect consumer attitudes towards advertisements and brands as well. This can lead to increased buying interest and thereby increase sales.

Wardah is very concerned about selecting celebrity endorsers. The criteria are how the endorsers can inspire those around them. Because Wardah Cosmetic is a cosmetic with a very distinctive character, therefore the company looks more at the inspirational story of the celebrity endorser and her desire to inspire (Swa.co.id, 2018).

Currently Wardah Cosmetic has spread throughout all parts of Indonesia, one of which is the city of Bandung, Bandung was once known as Paris van Java, because this city is considered to have similarities with the city of Paris, France. Apart from the atmosphere of a typical European city, like Paris which is known as the city of fashion, Bandung is also famous for the city of fashion. Young people who always look stylish and stylish, with creative ideas typical of Bandung youths which they pour into clothing, have always been a trendsetter and even Bandung has become a fashion barometer in the country. With the high awareness of the appearance of women in the city of Bandung, fashion and make-up are inseparable things because make-up is an important instrument to support the appearance. Therefore, Bandung is one of the most promising areas for Wardah Cosmetic, this is evidenced by the existence of several Wardah counters in several big malls in Bandung such as Bandung Indah Plaza, Cihampelas Walk, and Istana Plaza.

The selection of products and services that a person buys is further influenced by psychological factors, one of which is perception. By getting the top position in the first place on the Top Brand Award, it means that Wardah Cosmetic has succeeded in bringing out a good perceived quality for its consumers. The results of research conducted by Faraditta (2014) state that perceived quality has a positive direct influence on purchase intention. There is a relationship between perceived quality and purchase interest where perceived quality reflects consumers' assumptions or feelings about a brand as a whole.

Based on this phenomenon, researchers are interested in researching to know the effect of celebrity endorsers and Wardah Cosmetic's perceived quality on the buying interest of female consumers in Bandung. For this reason, researchers will research the title "The Influence of Celebrity Endorser on Purchase Intention with Perceived Quality Variable as Mediator".

\section{METHODS}

In this study, the type of research used is quantitative. The primary data source is obtained through a questionnaire (questionnaire). Meanwhile, based on its nature, this study uses associative-causality. There are two research variables used in this study, namely the independent variable consisting of Celebrity Endorser $(X)$, Perceived Quality (Y), and the dependent variable, namely Purchase Interest (Z).

The population in this study were Wardah Cosmetic female consumers in Bandung. Researchers used a sample of 100 respondents who had purchased products at Berrybenka. The sampling technique used non-probability sampling with purposive sampling method according to Siregar (2013), with a total sample of 100 people using the Isac Michel method. 
The types of data needed in this study are primary data and secondary data. Primary data collection techniques in this study using a questionnaire (questionnaire). The questionnaire was distributed using google forms: https://goo.gl/forms/3Upy8ZYO6OrU41 $\mathrm{Bq} 2$, while secondary data in this study were obtained from national journals, international journals, web, and previous research relevant to the topic under study.

The data analysis technique used in this study was the Structural Equation Model - Partial Least Square (SEM-PLS) method. The calculation of the validity test for the questionnaire was carried out using the convergent validity formula and the discriminant validity, while the reliability test used was using composite reliability. Both tests were carried out using the help of SmartPLS v.2.3.7 for Windows Software. Based on the results of the validity and reliability tests, the instruments in the study were declared valid and reliable.

\section{RESULTS AND DISCUSSION}

In using SEM-PLS, it is necessary to check the reliability of the indicators used as a measuring tool for latent variables. The reliability of an indicator can be accepted if $\geq 0.7$ (Ghozali \& Latan, 2015).

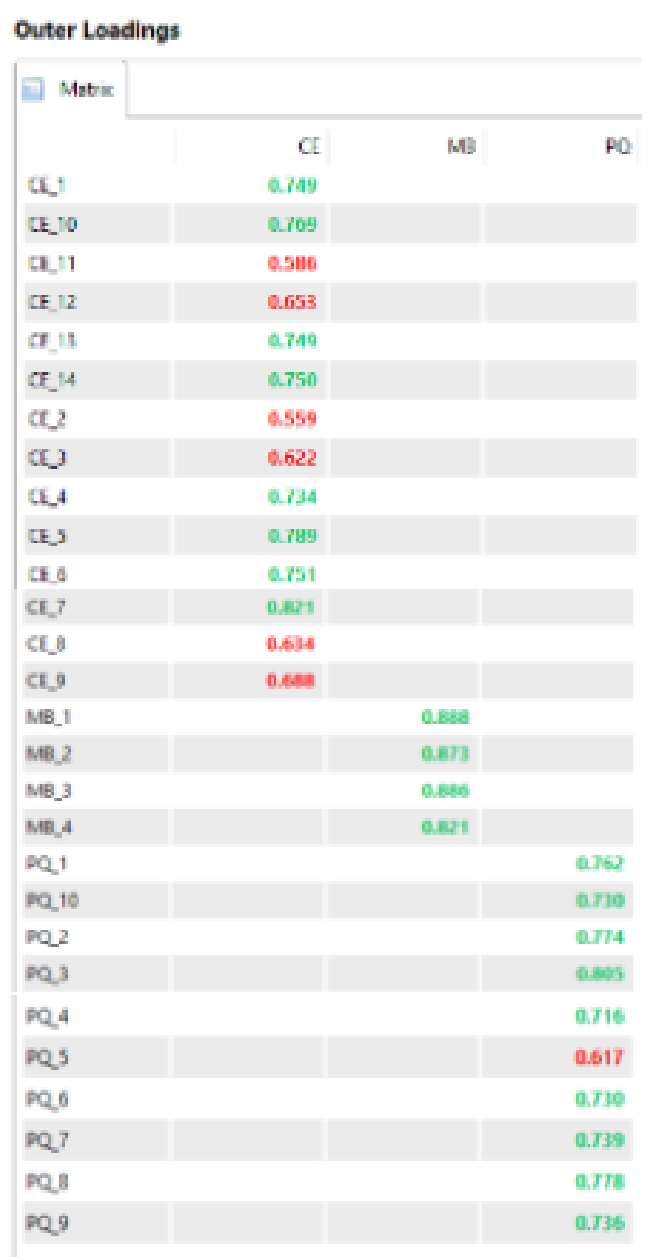

Figure 1. Results of per-Indicator Reliability Checks of Outer Loadings Source: The data is processed by the author

The results of the measurement analys Ts of outer loadings which we can see in Figure 3 show that there are 7 invalid indicators because the numbers are below $\geq 0.7$, so it is necessary to do a re-specification by not including invalid indicators. The indicator is CE_2 0.559 ; CE_3 0.622; CE_8 0.634; CE_9 0.688; CE_11 0.586; CE_12 0.653; and PQ_5 0.617 .

The Specification and Indirect Measurement Model (Outer Model) can be seen in the image below: 


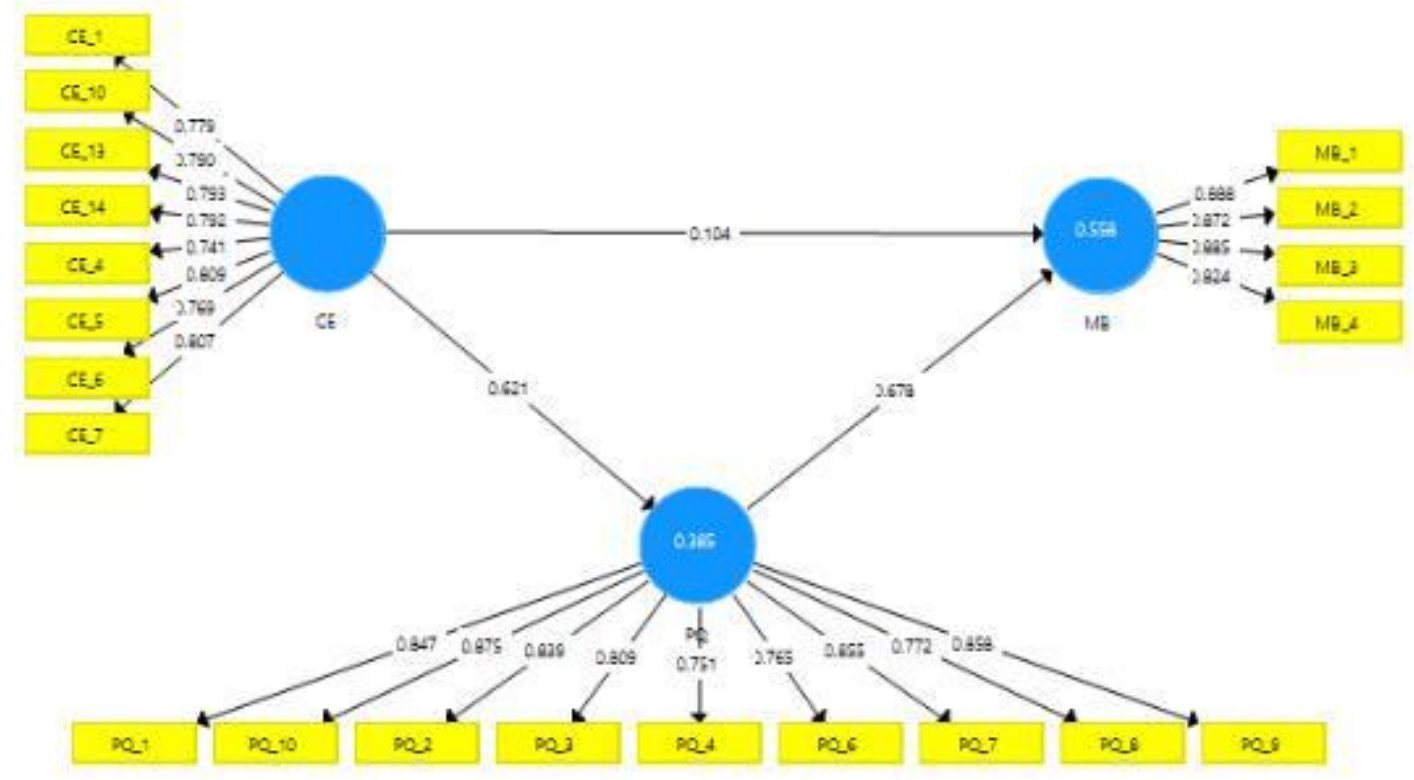

Figure 2. Path Coefficient

Source: PLS-Algorithm using SmartPLS 3.2.7 Respecification model

Then the indicators to be used are 21 indicators that have a reliable number $\geq 0.7$, including $\mathrm{CE} 1, \mathrm{CE} 4, \mathrm{CE} 5$, CE_6, CE_7, CE_10, CE_13, CE_14,

Table 1. Path Coefficient of Bootstrapping Indirect Model

\begin{tabular}{lcccc}
\hline & $\begin{array}{c}\text { Original } \\
\text { Sample (0) }\end{array}$ & $\begin{array}{c}\text { Sample } \\
\text { Mean } \\
(\mathbf{M})\end{array}$ & $\begin{array}{c}\text { Standard } \\
\text { Deviation } \\
\text { (STDEV) }\end{array}$ & $\begin{array}{c}\text { T Statistics } \\
\text { (|O/STERR|) }\end{array}$ \\
\hline CE $->$ MB & 0.104 & 0.097 & 0.093 & 1.124 \\
CE $>$ PQ & 0.621 & 0.634 & 0.062 & 9.945 \\
PQ $\rightarrow$ MB & 0.677 & 0.681 & 0.086 & 7.867 \\
\hline
\end{tabular}

Source: SmartPLS software v.3.1.3

In the picture above by using the software SmartPLS v.3.1.3 can analyze the significance using Bootstrapping which was developed by Efron in the 1970s to determine the effect between variables. In the Bootstrap procedure, re-sampling uses all empirical data or original samples (Ghozali \& Latan 2012).

\section{Hypothesis Testing Analysis of SEM- PLS}

We can find out whether the path coefficients of the structural model are
significant or not, it can be seen from the
T-Statistics value. According to Ghozali coefficients of the structural model are
significant or not, it can be seen from the
T-Statistics value. According to Ghozali coefficients of the structural model are
significant or not, it can be seen from the
T-Statistics value. According to Ghozali
$P_{1}$ 1, $P Q$ 2,$P Q$ 3, $P Q$ 4, $P Q$ 6, $P Q_{-7}, P Q$ 8, $P Q$ 9, $P P_{-10}, M B_{-1}^{-1}$, $M B \_2, M B \_3$,and $M B$ 4.
\& Latan (2015), the minimum value of TStatistics is to assess whether or not the relationship between one latent variable and other latent variables is significant depending on the significance value used, namely:(1) The significance level is $10 \%$, the T-Statistics value is $>$ or at least 1.65 ; (2) The significance level is $5 \%$, the T-Statistics value is $>$ or at least 1.96 ; (3) The significance level is $1 \%$, the T-Statistics value is $>$ or at least 2.58 . In this study, the researchers chose a significant level of $5 \%$, the path coefficient was considered significant if the T-Statistics value was more than 1.96 (Ghozali \& Latan 2015). 
Table 2. Hypothesis Test

\begin{tabular}{|c|c|c|c|c|c|}
\hline & Hypothesis & $\begin{array}{l}\text { Significance } \\
\text { of T-Statistics }\end{array}$ & $\begin{array}{c}\mathrm{T}- \\
\text { Statistics } \\
\text { value }\end{array}$ & Result & Description \\
\hline H1 & $\begin{array}{l}\text { Celebrity Endorser from } \\
\text { Wardah Cosmetic affect } \\
\text { Interests Purchase Wardah } \\
\text { Cosmetic at } \\
\text { women in the city of } \\
\text { Bandung }\end{array}$ & $>1.96$ & 7.486 & Be accepted & $\begin{array}{l}\text { T-Statistics value }> \\
1,96\end{array}$ \\
\hline H2 & $\begin{array}{l}\text { Celebrity Endorser from } \\
\text { Wardah Cosmetic effect on } \\
\text { Perceived Quality Wardah } \\
\text { Cosmetic in women in the } \\
\text { city Bandung }\end{array}$ & $>1.96$ & 9.945 & Be accepted & $\begin{array}{l}\text { T-Statistics value > } \\
1,96\end{array}$ \\
\hline H3 & $\begin{array}{l}\text { Perceived Quality from } \\
\text { Wardah Cosmetic affect } \\
\text { Interests Purchase Wardah } \\
\text { Cosmetic at } \\
\text { women in the city of } \\
\text { Bandung } \\
\text { Perceived Quality has a } \\
\text { role as intermediary } \\
\text { mediator Celebrity } \\
\text { Endorser with Buying } \\
\text { Interest Wardah Cosmetic } \\
\text { in women in the city of } \\
\text { Bandung }\end{array}$ & $>1.96$ & 7.867 & Be accepted & $\begin{array}{l}\text { T-Statistics value }> \\
1,96\end{array}$ \\
\hline H4 & $\begin{array}{l}\text { Perceived Quality has a } \\
\text { role as intermediary } \\
\text { mediator Cel } \\
\text { Endorser with Buying } \\
\text { Interest Wardah Cosmetic } \\
\text { in women in the city of } \\
\text { Bandung }\end{array}$ & $>1.96$ & 1.124 & Full Mediation & $\begin{array}{lr}\text { T-Statistics } & \text { value } \\
\mathrm{CE} \text { to } & \mathrm{MB} \\
\text { decreased after the } \\
\text { mediator variable } \\
\text { becomes } & 1.124 \\
\text { becomes } & \text { not } \\
\text { significant } & \end{array}$ \\
\hline
\end{tabular}

Source: The data is processed by the author using SEM PLS

From the table above, it can be seen that there is a significant influence among celebrity endorsers on Wardah Cosmetic's buying interest, it can be proven from the results of the PLS-SEM analysis where there is a significant value of T-statistics 7,486 which means that the hypothesis is accepted and it means that there is an influence positive celebrity endorser on consumer buying interest Wardah Cosmetic in the city of Bandung.

That celebrity endorsers can influence Wardah Cosmetic's perceived quality, can be proven by the results of the PLS-SEM analysis where there is a second hypothesis. obtained a significance value of T-statistics 9.954, which means that the hypothesis is accepted and it means that there is a positive influence of celebrity endorsers on the perceived quality of Wardah Cosmetic.

That perceived quality affects Wardah's consumer buying interest, it can be proven by the results of the PLSSEM analysis where the third hypothesis has a T-statistical significance value of 7,867 , which means that the hypothesis is accepted and it means that there is a positive effect of perceived quality on Wardah's buying interest. Cosmetic.

Proving that perceived quality affects a perfect mediator on celebrity 
endorsers and Wardah Cosmetic buying interest, this is evidenced from the results of the PLS-SEM analysis where the T-Statistics obtained is 1.124 , it can be concluded that this fourth hypothesis is rejected because the value is less than the level the specified significance. At first, the T-statistics celebrity endorser on purchase interest has a significant value of 7.486 , and after the mediator variable, the value of celebrity endorser on purchase interest becomes 1.124 decreases and becomes insignificant. This shows that there is the influence of $P Q$ being a perfect mediator that can mediate perfectly because when there is a mediator variable the effect of $X$ to $Z$ becomes completely through $\mathrm{Y}$. When there is a mediator variable it seems almost $100 \%$ of the influence of $\mathrm{X}$ to $\mathrm{Z}$ is through $\mathrm{Y}$.

\section{CONCLUSION}

There is a significant influence among celebrity supporters on buying interest in Wardah Cosmetics. celebrity endorser can influence the perceived quality of Wardah Cosmetic and there is a positive influence of celebrity endorser on the perceived quality of Wardah Cosmetic. Meanwhile, perceived quality affects Wardah consumer buying interest, there is a positive influence on the purchase intention of Wardah Cosmetics. perceived quality affects a perfect mediator on celebrity endorsers and Wardah Cosmetic buying interest

\section{REFERENCES}

Chinomona, R. (2013). The Impact Of Product quality On Perceived Value. Trust and Students Intention To Purchase Electronic Gadgets. Mediterraneam Journal Of Social Sciences, 4(14).

Damanik, T. B. (2015). Pengaruh Celebrity Endorser terhadap Minat Beli Kosmetik (Studi Kasus pada : Kosmetik Wardah).
Darmansyah, Salim, M., \& Bachri S. (2014). Pengaruh Celebrity Endorser terhadap Keputusan Pembelian Produk di Indonesia (Penelitian Online). Fakultas Ekonomi Manjemen Universitas Bengkulu. Jurnal Aplikasi Manajemen, 12(2).

Enciety.co. (2013). Bisnis Kosmetik Halal Tumbuh Di Atas 120 Persen. Indonesia.

http://www.enciety.co/bisniskosmetik-halal-tumbuh-di-atas120-persen

Faraditta, A., \& Mudiantono. (2015). Analisis Pengaruh Country of Origin Perception, Perceived Quality dan Consumer Perception terhadap Purchase Intention dengan Brand Image sebagai Variabel Intervening (Studi pada oli Fastron di Kota Semarang). Semarang: Fakultas Ekonomika dan Bisnis Universitas Diponegoro.

Ghozali, \& Latan. (2015). Partial Least Square (PLS) Konsep, Teknik dan Aplikasi Menggunakan Program Smartpls 3.0. Semarang: Badan Penerbit Universitas Diponegoro.

Ghozali, I., \& Latan, H. (2012). Partial Least Squares: Konsep, Teknik dan Aplikasi Menggunakan Program SmartPLS 2.0 M3. Semarang: Badan Penerbit Universitas Diponegoro.

Kertamukti, R. (2015). Strategi Kreatif Dalam Periklanan: Konsep, Media, Branding, Anggaran. Jakarta: Rajawali Pers.

Mansour , I. F., \& Diab, D. M. (2016). The relationship between celebrities' credibility and advertising effectiveness: The mediation role of religiosity. Journal of Islamic Marketing, 7(2), pp.148-166, https://doi.org/10.1108/JIMA-052013-0036.

Putra, Muhammad Ikhsan, Suharyono \& Yusri Abdillah (2014). Pengaruh Brand Ambassador Terhadap Brand Image Serta Dampaknya 
Almana : Jurnal Manajemen dan Bisnis Vol. 4 No. 3/ December 2020

ISSN 2579-4892 print/ ISSN 2655-8327 online

Terhadap Keputusan Pembelian. Jurnal Administrasi Bisnis (JAB). 12(1).

Siregar, S. (2013). Metode Penelitian Kuantitatif. Jakarta: Kencan Prenada Media Group. swa.co.id. (2018). Wardah. Perluas pasar, hal. brand.

swa.co.id. (2018). Wow, Indonesia Pasar Pertumbuhan Utama Industri Kecantikan ASEAN 